\title{
Effect of Time and Technique of Grafting for Quality Production of Nursery Plants of Dashehari Mango (Mangifera indica L.)
}

\author{
Syed Sami Ullah ${ }^{*}$, Sunil Malik ${ }^{2}$, Ranjeet Kumar ${ }^{2}$ and Mukesh Kumar ${ }^{2}$ \\ ${ }^{1}$ Division of Fruit Science, Sher-e-Kashmir University of Agricultural Sciences and Technology \\ of Kashmir, Shalimar, Srinagar, 190025, India \\ ${ }^{2}$ Department of Horticulture, SardarVallabhbhai Patel University of Agriculture and Technology, \\ Meerut, 250110, India \\ *Corresponding author
}

\section{A B S T R A C T}

\begin{tabular}{|l|}
\hline Ke y w or d s \\
Mango, Quality, \\
Grafting technique, \\
Plants. \\
\hline Article Info \\
\hline $\begin{array}{l}\text { Accepted: } \\
\text { 07 September } 2017 \\
\text { Available Online: } \\
\text { 10 October } 2017\end{array}$ \\
\hline
\end{tabular}

Field experiment was carried out to find the response of Dashehari mango to time (25 July, $10^{\text {th }}$ August and $25^{\text {th }}$ August) and techniques (Veneer, Softwood and Epicotyl) of grafting. Studies revealed that epicotyl grafting performed on $10^{\text {th }}$ August recorded minimum time (13.46 days) for bud sprouting, whereas veneer grafting performed on $10^{\text {th }}$ August was found to be the best technique in terms of sprouting percentage after one $(89.62 \%)$ and six $(82.30 \%)$ month of grafting. Therefore, veneer grafting should be preferred over softwood and epicotyl grafting in order to get better survival and over all sprout growth for commercial propagation of quality plants of Dashehari mango. The present investigation was conducted at Horticultural Research Centre, Sardar Vallabhbhai Patel University of Agriculture and Technology, Meerut, Uttar Pradesh, during 2013-14 under subtropical climatic conditions of western Uttar Pradesh with a view to find out the response of Dashehari mango to time and techniques of grafting

\section{Introduction}

Mango (Mangifera indica L.) is the most important crop among the tropical and subtropical fruits grown in more than 90 countries of the world. Mango is propagated by both sexual and asexual means, but plants raised by seed leads to enormous variability and are never true-to-type because it is cross pollinated and heterozygous in nature. The plants raised through seeds are tall and spreading type which causes lot of hazards in performing various cultural operations and also plants take long time to come into bearing. Therefore, asexual or vegetative methods are adopted to get true-to-type plants. The techniques of vegetative propagation which have been standardized in most of the fruit crops have substantially revolutionized the fruit industry in our country (Singh, 2009). Mango is propagated by veneer (Ram and Bist, 1982), softwood (Pathak and Ram, 2003) and epicotyl (Bhan et al., 1969 and Majumder and Rathore, 1970) grafting techniques for high success rate. The above three techniques have some pros and cons one upon the other. Veneer grafting fails to produce erect and stout plants of uniform canopy, which is one of the most important prerequisites for successful modern 
mangoorcharding (Singh, 2009). The success of grafting depends on numerous factors like temperature, relative humidity, light, soil moisture, aeration, age of rootstock, method and time of grafting, growing media and skill of grafter. Therefore, in order to make these techniques commercially efficient and economic, present investigation was carried out to assess the effect of different date and methods of grafting on success and growth of mango grafts.

\section{Materials and Methods}

The present investigation was conducted at Horticultural Research Centre, Sardar Vallabhbhai Patel University of Agriculture and Technology, Meerut, Uttar Pradesh, during 2013-14 under subtropical climatic conditions of western Uttar Pradesh. The experiment was carried out in factorial RCBD with five replications in each treatment. There were four grafts in each replication of all 9 treatment combinations. The treatment combinations were comprised of three time of grafting i.e. $\left(25^{\text {th }} \mathrm{July,} 10^{\text {th }}\right.$ August and $25^{\text {th }}$ August) with three methods of grafting viz, veneer grafting, softwood grafting and epicotyl grafting. The techniques as suggested by Mukherjee and Majumdar (1961) and Desai and Patil (1984) were followed for performing veneer and softwood grafting, respectively. The epicotyl grafting was performed by wedge technique as suggested by Mujumdar and Rathore (1970). One to two months old healthy scion shoots having 0.4 $\mathrm{cm}$ thickness and $8.0 \mathrm{~cm}$ length were selected from current season growth of mother tree of Dashehari. The selected scion shoots on mother plants were defoliated eight days before the actual operation and were detached from mother plant just prior to grafting operation. All the techniques of grafting were performed on $25^{\text {th }}$ July, 2013, $10^{\text {th }}$ August, 2013 and $25^{\text {th }}$ August, 2013. The grafting operation was completed on the same day.
The mango stones of unknown commercial cultivars were used for raising seedling rootstocks for grafting. These stones were sown in black poly bags. Veneer and softwood grafting were performed on oneyear-old seedlings, while epicotyl grafting was done on 10 day old seedlings. The media used for filling of poly bags consisting of soil, sand and FYM in the ratio of 1:1:1. Just after sowing of mango stone, watering was done with the help of sprinkler. The poly bags were then kept in net house.

\section{Results and Discussion}

\section{Effect of time and technique of grafting on days taken for bud sprouting in mango grafts after grafting}

The interaction effect of time and technique of grafting indicated that earliest sprouting was observed when epicotyl grafting was performed on $10^{\text {th }}$ August (13.46 days) and latest sprouting was observed when softwood grafting was performed on $25^{\text {th }}$ August (20.30 days) (Table 1). The interaction between time and technique of grafting on days taken for bud sprouting was also found to be significant. The findings of the current study are in accordance with the findings obtained by Singh et al., (2012)who observed earliest sprouting when grafting was done during wet season (July and August), while latest sprouting was recorded in September. Similarly, Islam and Rahim (2010) observed maximum time for bud sprouting (11.07 days) when grafting was done on 26 August, while, it was minimum (10.12 days) when grafting was performed on 6 August.

Effect of time and technique of grafting on per cent success in mango grafts after one months of grafting

The maximum per cent success after one month of grafting was observed when grafting 
was performed on $10^{\text {th }}$ August followed by $25^{\text {th }}$ July and $25^{\text {th }}$ August (Table 2). Among the treatments, veneer grafted grafts recorded the maximum per cent success followed by softwood and epicotyl grafted grafts.

The interaction effect of time and technique of grafting indicates that the maximum per cent success was observed in veneer grafting when performed on $10^{\text {th }}$ August $(89.62 \%)$ and minimum per cent success was observed in epicotyl grafting when performed on $25^{\text {th }}$ August (63.70\%).

The interaction effect between time and technique of grafting on per cent success were also found to be significant.
Effect of time and technique of grafting on per cent success in mango grafts after six month of grafting

The highest per cent success after six month of grafting was recorded when grafting operation was performed on $10^{\text {th }}$ August followed by $25^{\text {th }}$ July and $25^{\text {th }}$ August (Table $3)$. The interaction effect of time and technique of grafting on per cent success was highest when veneer grafting was performed on $10^{\text {th }}$ August $(82.30 \%)$ while as per cent success was least when epicotyl grafting was performed on $25^{\text {th }}$ August (59.54\%). The interaction between time and technique of grafting on per cent success were found to be significant.

Table.1 Effect of time and technique of grafting on days taken for bud sprouting in mango grafts after grafting

\begin{tabular}{|c|c|c|c|c|}
\hline \multirow{3}{*}{$\begin{array}{c}\text { Grafting } \\
\text { techniques } \\
\end{array}$} & \multirow{2}{*}{\multicolumn{3}{|c|}{$\begin{array}{c}\text { Cultivar Dashshari } \\
\text { Time of grafting }\end{array}$}} & \multirow[b]{3}{*}{ mean } \\
\hline & & & & \\
\hline & $\begin{array}{l}25^{\text {th }} \\
\text { July }\end{array}$ & $\begin{array}{c}10^{\text {th }} \\
\text { August }\end{array}$ & $\begin{array}{c}25^{\text {th }} \\
\text { August }\end{array}$ & \\
\hline Softwood & 18.05 & 16.12 & 20.30 & 18.16 \\
\hline Veneer & 17.10 & 14.78 & 18.90 & 16.96 \\
\hline Epicotyl & 16.25 & 13.46 & 17.40 & 15.70 \\
\hline Mean & 17.13 & 14.79 & 18.87 & 16.93 \\
\hline C.D. at $5 \%$ & 0.63 & 1.30 & 1.37 & \\
\hline
\end{tabular}

Table.2 Effect of time and technique of grafting on days per cent success in mango grafts after one month of grafting

\begin{tabular}{|l|c|c|c|c|}
\hline \multirow{2}{*}{\begin{tabular}{|l|c|} 
Grafting \\
techniques
\end{tabular}} & $\begin{array}{c}|c| \\
\mathbf{2 5}^{\text {th }} \\
\text { July }\end{array}$ & $\begin{array}{c}\mathbf{1 0}^{\text {th }} \\
\text { August }\end{array}$ & $\begin{array}{c}\mathbf{2 5}^{\text {th }} \\
\text { August }\end{array}$ & \multirow{2}{*}{ mean } \\
\hline Softwood & 82.40 & 85.44 & 79.8 & 82.55 \\
\hline Veneer & 84.24 & 89.62 & 81.9 & 85.25 \\
\hline Epicotyl & 65.22 & 69.42 & 63.7 & 66.11 \\
\hline Mean & 77.29 & 81.49 & 75.13 & 77.97 \\
\hline C.D. at 5\% & 1.81 & $\mathbf{1 . 6 3}$ & $\mathbf{1 . 1 7}$ & \\
\hline Date-0.589:Grafting-0.589: Date $\times$ Grafting-1.020 \\
\hline
\end{tabular}


Table.3 Effect of time and technique of grafting and scion cultivars on per cent success in mango grafts after six month of grafting

\begin{tabular}{|c|c|c|c|c|}
\hline & \multirow{2}{*}{\multicolumn{3}{|c|}{$\begin{array}{c}\text { Cultivar Dashehari } \\
\text { Time of grafting }\end{array}$}} & \multirow[b]{3}{*}{ mean } \\
\hline & & & & \\
\hline $\begin{array}{c}\text { Grafting } \\
\text { techniques }\end{array}$ & $\begin{array}{l}25^{\text {th }} \\
\text { July }\end{array}$ & $\begin{array}{c}10^{\text {th }} \\
\text { August }\end{array}$ & $\begin{array}{c}25^{\text {th }} \\
\text { August }\end{array}$ & \\
\hline Softwood & 73.64 & 78.6 & 69.46 & 73.9 \\
\hline Veneer & 76.2 & 82.3 & 72.4 & 76.97 \\
\hline Epicotyl & 62.8 & 65.2 & 59.54 & 62.51 \\
\hline Mean & 70.88 & 75.37 & 67.13 & 71.12 \\
\hline C.D. at $5 \%$ & 1.75 & 1.36 & 1.43 & \\
\hline \multicolumn{5}{|c|}{ Date-0.464:Grafting-0.464 : Date $\times$ Grafting-0.804 } \\
\hline
\end{tabular}

Effect of time and technique of grafting on days taken for bud sprouting, per cent success in mango grafts after one and six month of grafting

Earlier emergence during the first and second week of August in the present study might be due to the favourable temperature and relative humidity prevailing at that time. Moderate temperature and high humidity prevailing during rainy season (July-August) in the region accelerate the graft union formation and subsequently sprouting of shoots. This fact became clear when the correlation with meteorological observations were worked out. The data indicated negative correlation between the days taken for sprouting and temperature, humidity and rainfall. The favourable climatic conditions i.e., high humidity, high rainfall with moderate temperature prevailed during August, July and September reduces the time required for bud sprouting. In the present investigation days taken for sprouting of scion was found to be negatively correlated with the sprouting per cent and success percent. The delay in sprouting resulted in decrease in sprouting per cent. It was probably because of the fact that reduced translocation of solutes and nonavailability of vital bio-chemical compounds in the grafts for longer period resulted in desiccation. The higher success in the current study during wet season might be because of congenial environmental conditions prevailing during the period following grafting and rapid sap flow in stock and scion which might have favoured the healing process and caused early callus formation and as a result established the continuity of cambium and vascular tissues for sprouting and ultimately higher plant survival (Chandal et al., 1998; Pathak and Srivastava, 1973).

Various workers under different climatic conditions have studied the influence of different techniques of grafting on bud break and survival per cent in mango (Bajpai et al., 1989; Brahmachari et al., 1999; Jane, 2007; Kumar et al., 2000; Mngomba et al., 2010). Singh et al., (2012) observed that among different techniques of grafting, veneer grafting took minimum number of days (17.00) for bud sprouting as compared to other methods of grafting. Similarly, the sprout initiation in veneer grafting in the present study took about 17.33 days. The findings of present study obtained on the above aspects are quite comparable to the findings of earlier workers namely; Kumar et al., (2000) and Sabeky (2005). The later researcher had reported highest success in veneer $(65.8 \%)$ than softwood $(63.7 \%)$ 
grafting. The earliest sprouting in veneer grafting in the present study might be due to early and better contact of cambial layers of stock and scion resulting in early callus formation as compared to those grafted by softwood grafting. The other possible reason for earliest sprouting with this technique can be attributed to the firmness with which the scion stick is held with the stem of rootstock without any interference from the plant tissue (Roy et al., 1999).

The findings of the current study therefore suggested that acceleration of scion growth of veneer grafts might be due to the fact that early bud sprouting in veneer grafts favoured early callus formation resulting in the rapid graft union process. As a result, such grafts made good vegetative growth in comparison to softwood grafting, in which late initiation of subsequent growth occurred due to delay in sprouting. Therefore, veneer grafting should be preferred over softwood and epicotyl grafting in order to get better survival and over all sprout growth for commercial propagation of quality plants of Dashehari mango in polybags.

\section{Acknowledgements}

I extend my worthy and sincere gratitude to Dr. H.S Gaur (Hon'ble Vice Chancellor), Dr. Devi Singh (Director Research), Dr. S.A. Kerkhi (Dean, P.G.S), my Advisor Dr. Sunil Malik and esteemed members of my Advisory Committee of Sardar Vallabhbhai Patel University of Agriculture \& Technology, Meerut, (U.P.) for providing necessary facilities during the course of study.

\section{References}

Bajpai, P. N., Singh, A. R., Yati, V. and Chaturvedi, O. P. 1989. Effect of cultivars and age of rootstocks on the performance of veneer grafting in mango. ActaHorticulturae; (231):259262.

Bhan, K. C., samaddar, H. N. and Yadav, P. C. 1969. Chip budding and stone grafting of mangoes in India. Tropical Agriculture trinudad; 40:247-253.

Brahmachari, V. S., Singh, M. P. and Bishwas, R. C. 1999. Effect of period of defoliation of scion and age of rootstock on success of epicotyl grafting in mango (Mangiferaindica L.) cv. Amrapali. Orissa Journal of Horticulture; 27(2):14.

Chandel, J. S., Negi, K. S. and Jindal, K. K. 1998. Studies on vegetative propagation in Kiwi (Actinidia deliciosachev.) Indian Journal of Horticulture; 55:5254

Desai, J. B., and Patil, V. K. 1984. Success of stone grafting in mango in glasshouse and in open. The Punjab horticultural journal; 24: 7-10. (1-2): 45-49.

Islam, M. R., and Rahim, M. A. 2010. Performance of epicotyl grafting in different varieties of mango. Journal of Agroforestry and Environment; 4(1):4550.

Jana, B. R., 2007. Response of different mango cultivars to top-veneer grafting. Journal of Research, Birsa Agricultural University; 19(1):91-94.

Kumar, S., Sant Ram, and Singh, C. P. 2000. Success of veneer and cleft grafting at different grafting heights of seedling rootstocks in Dashehari Mango. Indian Journal of Horticulture; 57: (3): 212214.

Majumdar, S. K., and Rathore, D. S. 1970. Epicotyl grafting in mango (Mangifera indica L.). Current Science; 39:42.

Mng'Omba, S. A., Akinnifesi, F. K., Sileshi, G. and Ajayi, O. C. 2010. Rootstock growth and development for increased graft success of mango (Mangifera indica) in the nursery. African Journal of Biotechnology; 9(9):1317-1324. 
Mukherjee, S. K., and Majumder, P. K. 1961. Veneer grafting in mango has its own advantages. Indian Horticulture; 6: 3 .

Pathak, P. K., and Srivastava, R. P. 1973. Studies on the vegetative propagation of apple. Propagation by grafting. Progressive Horticulture; 4(3/4):57-70.

Pathak, R. K., and Ram, R. A. 2003. Mango propagation. Phalphool (ICAR Publication), 25 (4); 9.

Ram, S., and Bist, L. D. 1982. Studies on veneer grafting of mango in Tarai. The Punjab Horticultural Journal; 22:64-71

Roy, S., Sinha, A. K. Singh, U. S. P. 1999. Detached methods of propagation in mango (Mangifera indica L.). Journal of Allied Biology; 9(1): 14-16
Sabeky, E., 2005. Study and determination of the best time and method for mango grafting in Bahukalat, Sistan Baluchestan Province. Journal of Science and Technology of Agriculture and Natural Resources; 9(1): 91-101.

Singh, R. R., Karuna, K. Kumar, A. and Mankar, A. 2012. Studies on the effect of time and methods of grafting on success and growth of mango graft. Progressive Horticulture; 44(1): 151154.

Singh, R.N., 2009. Establishing the orchard in mango. Indian Council of Agricultural Research, New Delhi.

\section{How to cite this article:}

Syed Sami Ullah, Sunil Malik, Ranjeet Kumar and Mukesh Kumar. 2017. Effect of Time and Technique of Grafting for Quality Production of Nursery Plants of Dashehari Mango (Mangifera indica L.). Int.J.Curr.Microbiol.App.Sci. 6(10): 685-690. doi: https://doi.org/10.20546/ijcmas.2017.610.084 